\title{
Influence of Integrated Plant Nutrition System on Growth, Development and Yield of Wheat in Rice-Wheat Cropping System in Hilly Area of India
}

\author{
Gunjan Guleria $^{1 *}$, S.S. Rana $^{1}$, Rachana Rana ${ }^{1}$ and Amit Kumar Singh ${ }^{2}$ \\ ${ }^{1}$ Department of Agronomy, Forage and Grassland Management, College of Agriculture, CSK \\ Himachal Pradesh Krishi Vishwavidyalaya, Palampur (176062) (H.P.), India \\ ${ }^{2}$ ICAR-Indian Grassland and Fodder Research Institute, Jhansi (28400) (U.P.), India \\ *Corresponding author
}

\section{Keywords \\ Growth, Development, Integrated plant nutrition system, Rice-wheat cropping system, Wheat yield}

Article Info

Accepted: 06 August 2018 Available Online: 10 September 2018

\section{A B S T R A C T}

The present investigation was undertaken in a long-term experiment on IPNS in rice-wheat cropping system at the Badiarkhar farm of CSK HPKV Palampur Himachal Pradesh. Twelve treatments viz., control (no fertilizer/manure), 50, 75 and 100\% NPK each to rice and wheat through fertilizers, $50 \%$ NPK to rice and $100 \%$ NPK to wheat through fertilizers, 50\% substitution of $\mathrm{N}$ through FYM, wheat straw and green manure in rice and $100 \%$ NPK through fertilizers in wheat; $25 \%$ substitution of N through FYM, wheat straw and green manure in rice and $75 \%$ NPK through fertilizers in wheat; and farmers' practice (40\% NPK through fertilizers to each crop plus $5 \mathrm{t} \mathrm{FYM/ha} \mathrm{on} \mathrm{dry} \mathrm{weight} \mathrm{basis} \mathrm{to} \mathrm{rice)}$ were evaluated for a period of two years (2014-15 and 2015-16) with four replications. Increasing level of NPK application to wheat increased the number of shoots per metre square, maximum being in the treatment $\mathrm{T}_{6}(50 \% \mathrm{NPK}$ with $50 \% \mathrm{~N}$ through FYM to rice and $100 \%$ NPK was applied through fertilizers to wheat) and lowest in $\mathrm{T}_{1}$ (control) during both years. Significantly more plant height of wheat was recorded when application of $100 \%$ NPK to each crop was made $\left(\mathrm{T}_{5}\right)$ during 2014-15 and 50\% NPK with 50\% N through FYM to rice and 100\% NPK to wheat $\left(\mathrm{T}_{6}\right)$ during 2015-16. Shortest crop stature was recorded under $\mathrm{T}_{1}$ (control) during both the years. The minimum days to flowering and maturity in wheat were in $\mathrm{T}_{6}$ during both the years. $\mathrm{T}_{6}$ gave significantly higher grain and straw yield of wheat during 2015-16. On an average $\mathrm{T}_{6}$ where 50\% NPK in combination with 50\% N (FYM) was applied to rice and 100\% NPK to wheat was found to be the best treatment for getting higher productivity and profitability. Treatments have significant effect on grain yield of wheat during 2015-16 and straw yield during both the years.

\section{Introduction}

Of the 30 major cropping systems identified in India (Yadav and Prasad, 1998), rice-wheat cropping system is the most predominant in India occupying around $10.5 \mathrm{~m}$ ha area
(Sharma 2009). Among cereals, rice and wheat are the most important crops, which account for about $60 \%$ of world's human energy requirement. This system contributes about $75 \%$ of the nation's total food grain production, thus forms the backbone of food security (Lathwal et al., 2010). Wheat 
occupies a principal place in the diet of humans globally, contributing more to our daily calorie and protein intake than any other crop (Meulen and Chauhan 2017). In India, total area under wheat is 30.9 mha with production of $93.5 \mathrm{mt}$ (Anonymous 2016). It has tremendously helped the socio-economic development of the rural population in India. Farmers realize much of their food security from this cropping system. Besides food security, the low production levels jeopardize farmers' economic security to a considerable extent. The top most priority to meet the food demand of expanding human population is to increasing productivity of main grain crops. To strengthen the economic conditions of the farmers, it is imperative to sustain the productivity of this system. However, fertilizers are the kingpin in increasing crop productivity. But in case of intensive cultivation, growing exhaustive crops, use of unbalanced and inadequate fertilizers accompanied by restricted use of organic manures and biofertilizers have made the soils not only deficient in the nutrients, but also deteriorated in its health resulting in decline in crop response to the recommended dose of $\mathrm{N}$ fertilizer. Under such a situation, integrated nutrient management (INM) has assumed a great importance and has vital significance for the maintenance of soil productivity. INM involving the use of fertilizers along with organic sources of nutrient such as FYM, GM and crop residues is a precious research outcome to restore productivity. INM, the managerial aspect of integrated plant nutrition system (IPNS) is more vital in sustaining increased productivity (Yadav and Kumar, 2009). The integrated use of organic manures and inorganic fertilizers can help to maintain optimum crop yields and long term soil productivity (Puli et al., 2016). Farmers mostly use organic sources alone but their availability as per the requirement is a problem. The importance of leguminous green manure (GM) crops in improving soil fertility and soil physical properties has received increasing attention in recent past (Ray and Gupta 2001). Organic manures, particularly GM and farmyard manure (FYM), not only supply macronutrients but also meet the requirement of micronutrients, besides improving soil health.

\section{Materials and Methods}

Geographically, the experimental site is situated at $32^{\circ} 6^{0} \mathrm{~N}$ latitude, $76^{\circ} \quad 3^{0} \mathrm{E}$ longitude and $1223.7 \mathrm{~m}$ altitude in North Western Himalaya in the Palam Valley of Kangra district of Himachal Pradesh. The present study was undertaken during 2014 and 2015 in an ongoing long - term experiment which was initiated during kharif 1991 with rice - wheat cropping system at the Bhadiarkhar farm of CSK HPKV Palampur university. Palampur represents the subtemperate humid zone of Himachal Pradesh which is characterized by mild summers and cool winters. The area receives a very high rainfall during monsoon and medium to high rainfall with an occasional snowfall during winters. Agro-climatically, the experimental site falls in the sub-temperate zone in the midhills of Shivalik ranges of Himalayas which is endowed with mild summers and cool winters along with high rainfall during south-west monsoons. Average rainfall at the experimental site is $2600 \mathrm{~mm} /$ annum, major portion of which $(80 \%)$ is received during monsoon season (June to September). The soil of the experimental site was silty clay loam in texture, acidic in nature $(\mathrm{pH} 5.5)$, high in available nitrogen $(675 \mathrm{~kg} / \mathrm{ha})$, medium in available $\mathrm{P}(22 \mathrm{~kg} / \mathrm{ha})$ and $\mathrm{K}(221 \mathrm{~kg} / \mathrm{ha})$ with CEC of $11.5 \mathrm{c}$ mol $(\mathrm{p} \pm)$. Taxonomically the soils of the region are classified as 'Typic Hapludalf'. The field experiment was established with rice and wheat as test crops. In this field investigation, 12 treatments were evaluated in a randomized block design with four replications which are as follows (Table 
1).

In farmers' practice, FYM 5 t/ha was applied along with $40 \%$ NPK to rice followed by $40 \%$ NPK to wheat. The recommended $(100 \%)$ dose of nutrients in rice and wheat was 90:40:40 and 120:60:30 kg N, $\mathrm{P}_{2} \mathrm{O}_{5}$ and $\mathrm{K}_{2} \mathrm{O} /$ ha, respectively. Samples of organic sources were analyzed for $\mathrm{N}, \mathrm{P}$ and $\mathrm{K}$ contents as per the methods before application in rice season and data have been reported in Table 2 . Quantity of farmyard manure (FYM), wheat cut straw (WCS) and ex-situ green manure (GM) used in the experiment were worked out on field weight basis and incorporated before transplanting of rice.

\section{Crop studies}

\section{Growth studies}

The observations on growth characters viz., plant height and number of shoots (plant population) was recorded at monthly interval in wheat crop. For these observations, one outer row on all sides was left as border rows and the following one row on both sides were used for dry matter accumulation studies. The procedures adopted for recording of observations on various growth parameters are described here as under:

\section{Plant height}

Height of five randomly selected plants in the net plot area were measured from the soil surface to the tip of tallest leaf or tip of wheat spike and mean height was worked out.

\section{Number of shoots}

In case of wheat, $1 \mathrm{~m}$ row length was marked with sticks at two observation units in the net plot area. Total numbers of shoots in metre row length was counted at intervals mentioned as above and mean value was converted to number of shoot $/ \mathrm{m}^{2}$ of rice and wheat.

\section{Development studies (Phenophases)}

\section{Days to heading/flowering}

In case of wheat the $1 \mathrm{~m}$ row length marked for shoot counting was utilized for recording $75 \%$ heading stage. When $75 \%$ of the total shoots in $1 \mathrm{~m}$ row length borne spikes, the date was noted as heading/flowering date. The number of days after sowing was worked out as days taken for heading/flowering.

\section{Days to maturity}

In case of wheat one metre row length was again utilized for recording maturity stage and when $75 \%$ of the grains attained hard dough stage, the date was noted as maturity stage and number of days required were worked out from date of sowing.

\section{Results and Discussion}

\section{Crop-weather interaction}

The performance of any crop depends on the interaction between genetic and environmental factors. The environment plays an important role in influencing growth, development and ultimately the yield of a crop. Among the various environmental factors, weather parameters like ambient temperature, rainfall, sunshine hours and relative humidity play an important role. In rabi 2014-15 and 2015-16 (November to May), average monthly maximum temperature ranged between 15.2 to $30.1^{\circ} \mathrm{C}$ and 16.6 to $30.5^{\circ} \mathrm{C}$, respectively (Fig. 1). The average monthly minimum temperature ranged between 4.0 to $17.6^{\circ} \mathrm{C}$ and 3.5 to $17.0^{\circ} \mathrm{C}$ in 2014 and 2015 , respectively. It indicated that temperature during the crop cycle was favourable for germination, development and yield of wheat as ideal temperature range for successful wheat 
cultivation has been reported to be between 25 to $30^{\circ} \mathrm{C}$ (Arnon, 1972). The crop experienced well distributed rainfall of $367.2 \mathrm{~mm}$ and $682.9 \mathrm{~mm}$ in the first and second year, respectively which was in the optimum range of 360-630 mm (Reddy, 2004). The highest monthly total rainfall of $203.0 \mathrm{~mm}$ and 140.0 $\mathrm{mm}$ during the first and second year, respectively, was in March. The mean relative humidity during the crop season of first and second year was between 58 to $75 \%$ and 41 to $66 \%$, respectively. The overall weather conditions were favorable for growth and development of wheat as well as rice.

\section{Plant population (No./m²)}

Data on plant population at 90 DAS presented in Table 3 reveal that the increasing level of NPK application to wheat increased the number of shoots $/ \mathrm{m}^{2}$, maximum being in the treatment $\mathrm{T}_{6}(50 \% \mathrm{NPK}$ and $50 \% \mathrm{~N}$ through FYM to rice and $100 \%$ NPK was applied through fertilizers to wheat) and lowest in $\mathrm{T}_{1}$ (control) during both years. Regulation of shoot/root growth under homogeneous $\mathrm{N}$ supply has been attributed to nutrient availability, particularly to $\mathrm{N}$ or $\mathrm{C}$ partitioning. However, $\mathrm{T}_{6}$ did not produce significant difference from $\mathrm{T}_{7}(75 \% \mathrm{NPK}$ and $25 \% \mathrm{~N}$ through FYM to rice and $75 \%$ NPK to wheat), $\mathrm{T}_{10}(50 \% \mathrm{NPK}$ and $50 \% \mathrm{~N}$ through GM to rice and $100 \%$ NPK to wheat), $T_{11}(75 \%$ NPK and $25 \% \mathrm{~N}$ through GM to rice and $75 \% \mathrm{NPK}$ to wheat) and $\mathrm{T}_{12}$ (Farmers' practice) during 2014-15. The results are in conformity with Parewa and Yadav (2014).

\section{Plant height (cm)}

Nitrogen element is the nutrient that most frequently limits yield and plays an important role in quality of crops. Significantly more plant height was recorded when application of $100 \%$ NPK to each crop was made $\left(\mathrm{T}_{5}\right)$ during 2014-15 and 50\% NPK and 50\% N through
FYM to rice and $100 \%$ NPK to wheat $\left(\mathrm{T}_{6}\right)$ during 2015-16 (Table 3). Shortest crop stature was recorded under $\mathrm{T}_{1}$ (control) during both the years. It is interesting to note that application of $100 \%$ NPK to both rice and wheat $\left(\mathrm{T}_{5}\right)$ had no significant difference with any treatment except $T_{1}$ (Control) and $T_{2}$ (50\% NPK through chemical fertilizer) to each crop, in influencing plant height during 201415 . $\mathrm{T}_{6}$, however, produced significantly taller plants over all other treatments during 201516 when the difference from $\mathrm{T}_{5}(100 \%$ NPK to each crop), $\mathrm{T}_{7}(75 \% \mathrm{NPK}$ and $25 \% \mathrm{~N}$ through FYM to rice and $75 \%$ NPK to wheat) and $\mathrm{T}_{11}$ (75\% NPK and $25 \% \mathrm{~N}$ through GM to rice and $75 \%$ NPK to wheat) was not significant. Khoshgoftarmanesh and Kalbasi (2002); ElGizawy (2009) had also obtained improved crop growth by the use of organic materials in the form of organic manure or FYM. Ibrahim et al., (2008) have demonstrated the improvement of wheat growth and plant population with the use of organic manure and compost compared with chemical fertilizer. It is quite possible to get higher wheat yield by the integrated use of organic and inorganic fertilizers. Application of FYM was found to be responsible for improvement in different physiological characters in wheat viz., Chlorophyll- a, b content and heat stress tolerance of crop (Kowsar and Boswal, 2015). Increase in plant height and grain yield due to the increased levels of NPK fertilizers combined with FYM was reported by Parewa and Yadav (2014) and Kalhapure et al., (2015).

\section{Developmental stages}

Perusal of data on days taken to flowering in Table 4 reveals that significantly lowest number of days (117) was recorded in $\mathrm{T}_{6}$ (50\% NPK and 50\% $\mathrm{N}$ through FYM to rice and $100 \%$ NPK to wheat) both during 2014-15 and 2015-16. 
Table.1 Details of treatments in rice-wheat cropping system

\begin{tabular}{|c|c|c|}
\hline Treatment & Kharif & Rabi \\
\hline $\mathbf{T}_{1}$ & Control (No fertilizer, no manures) & Control (No fertilizer, no manures) \\
\hline $\mathbf{T}_{2}$ & $50 \% \mathrm{NPK}^{*}$ through fertilizer & $50 \%$ NPK through fertilizer \\
\hline $\mathbf{T}_{3}$ & $50 \%$ NPK through fertilizer & $100 \%$ NPK through fertilizer \\
\hline $\mathbf{T}_{4}$ & 75\% NPK through fertilizer & $75 \%$ NPK through fertilizer \\
\hline $\mathbf{T}_{5}$ & $100 \%$ NPK through fertilizer & $100 \%$ NPK through fertilizer \\
\hline $\mathrm{T}_{6}$ & $\begin{array}{l}50 \% \mathrm{NPK}+50 \% \mathrm{~N} \text { through farmyard manure } \\
(\mathrm{FYM})\end{array}$ & $100 \%$ NPK through fertilizer \\
\hline $\mathbf{T}_{7}$ & $75 \% \mathrm{NPK}+25 \% \mathrm{~N}$ through farmyard manure & 75\% NPK through fertilizer \\
\hline $\mathbf{T}_{8}$ & $\begin{array}{l}50 \% \mathrm{NPK}+50 \% \mathrm{~N} \text { through wheat cut straw } \\
\text { (WCS) }\end{array}$ & $100 \%$ NPK through fertilizer \\
\hline $\mathbf{T}_{9}$ & $75 \% \mathrm{NPK}+25 \% \mathrm{~N}$ through wheat cut straw & $75 \%$ NPK through fertilizer \\
\hline$T_{10}$ & $50 \% \mathrm{NPK}+50 \% \mathrm{~N}$ through green manure (GM) & $100 \%$ NPK through fertilizer \\
\hline $\mathrm{T}_{11}$ & $75 \% \mathrm{NPK}+25 \% \mathrm{~N}$ through green Manure & $75 \%$ NPK through fertilizer \\
\hline $\mathbf{T}_{12}$ & Farmers' practice $(40 \% \mathrm{NPK}+5 \mathrm{t} \mathrm{FYM} / \mathrm{ha})$ & $\begin{array}{l}\text { Farmers' practice }(40 \% \text { NPK through } \\
\text { fertilizer) }\end{array}$ \\
\hline
\end{tabular}

Table.2 Nitrogen, phosphorus and potassium contents (\%) of organics (dry wt. basis)

\begin{tabular}{|l|l|l|l|}
\hline Organics & $\mathrm{N}$ & $\mathrm{P}$ & $\mathrm{K}$ \\
\hline FYM (Cow dung manure) & 1.20 & 0.225 & 1.013 \\
\hline Wheat cut straw & 0.46 & 0.048 & 1.300 \\
\hline Green manure (Dhaincha) & 2.40 & 0.163 & 1.556 \\
\hline
\end{tabular}

Table.3 Effect of treatments on plant population $\left(\mathrm{No} . / \mathrm{m}^{2}\right)$ and plant height $(\mathrm{cm})$ of wheat

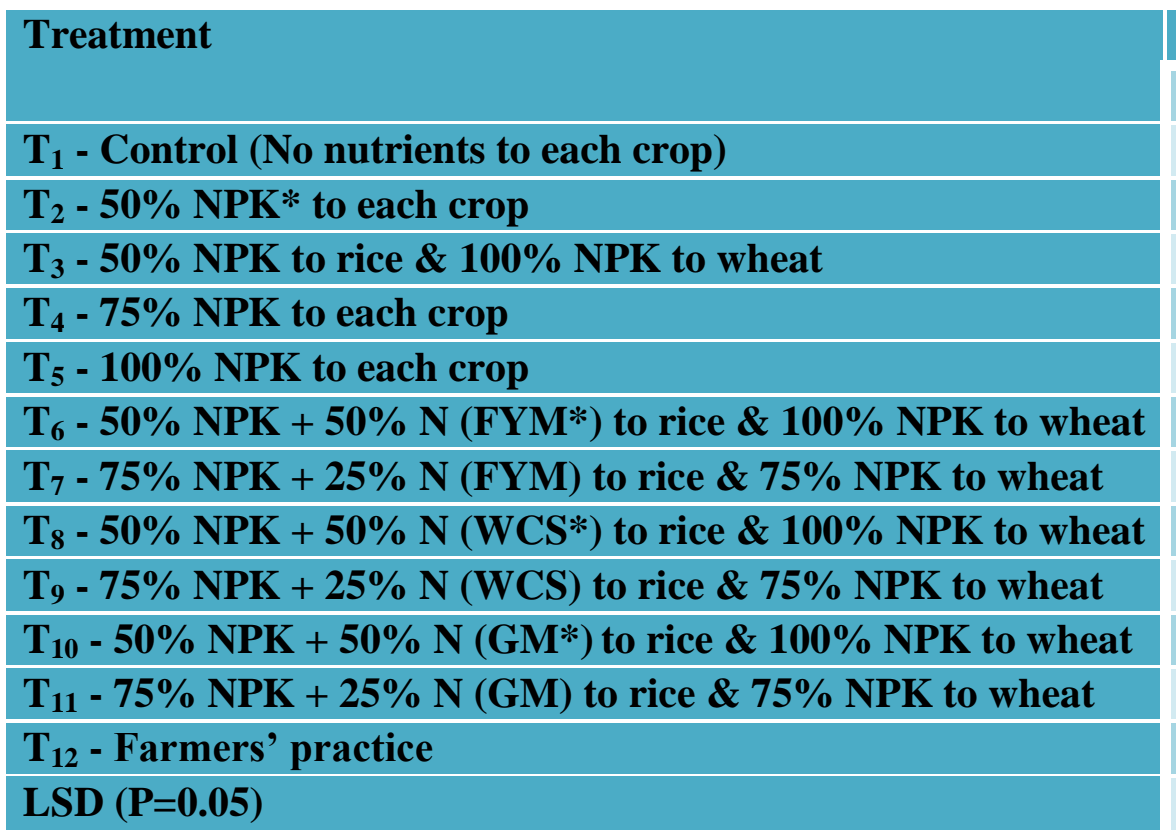

\begin{tabular}{|c|c|c|c|c|}
\hline Plant population & \multicolumn{2}{|c|}{ Plant height } \\
\hline 2014-15 & $\mathbf{2 0 1 5 - 1 6}$ & $\mathbf{2 0 1 4 - 1 5}$ & $\mathbf{2 0 1 5 - 1 6}$ \\
\hline 305.3 & 277.4 & 61.4 & 81.4 \\
\hline 318.7 & 327.4 & 79.7 & 86.9 \\
\hline 334.4 & 330.0 & 85.1 & 86.0 \\
\hline 351.2 & 367.8 & 88.6 & 86.6 \\
\hline 352.5 & 390.0 & 92.0 & 91.6 \\
\hline 376.8 & 416.5 & 85.3 & 92.4 \\
\hline 365.5 & 374.6 & 90.9 & 89.1 \\
\hline 351.9 & 331.2 & 87.3 & 84.8 \\
\hline 344.8 & 346.4 & 89.3 & 84.0 \\
\hline 363.1 & 343.6 & 84.5 & 84.2 \\
\hline 357.4 & 376.3 & 88.7 & 89.5 \\
\hline 358.9 & 334.1 & 84.0 & 86.3 \\
\hline 23.8 & 24.8 & 8.8 & 4.9 \\
\hline
\end{tabular}

*NPK- Through fertilizers, FYM- Farmyard manure, WCS- Wheat cut straw, GM- Green manure 
Table.4 Effect of treatments on days taken to flowering and maturity in wheat

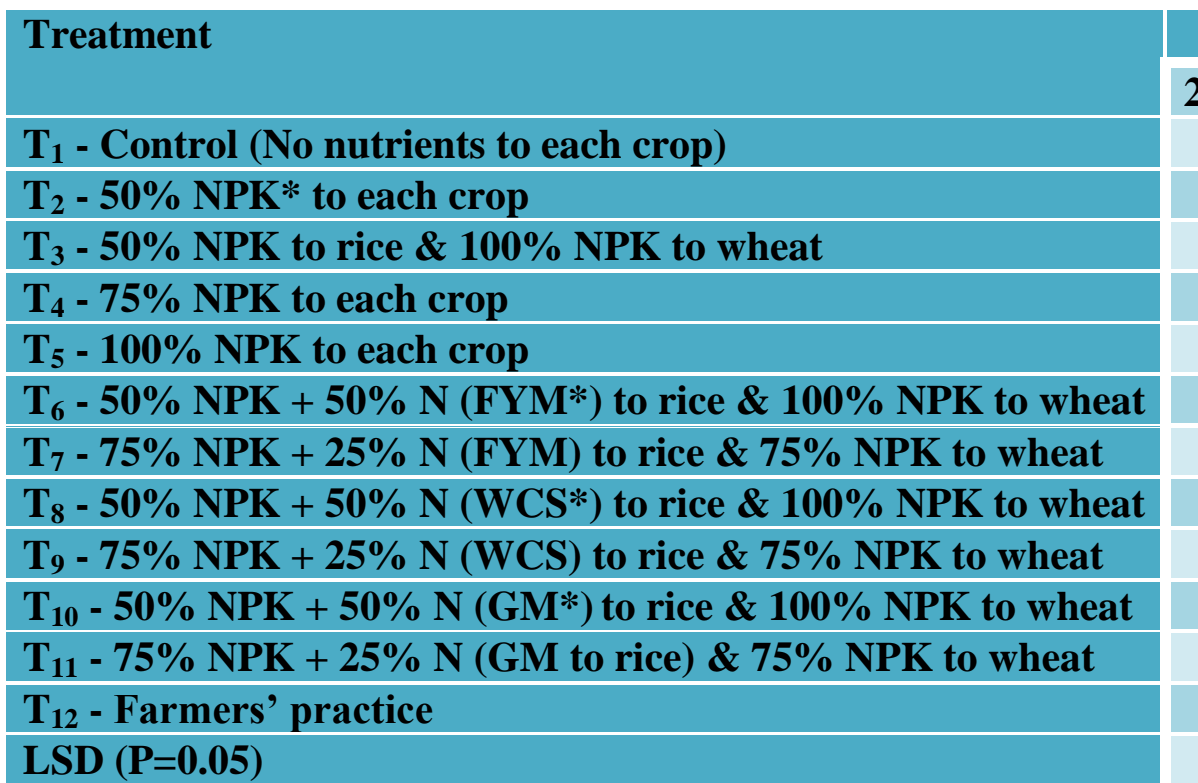

\begin{tabular}{|c|c|c|c|}
\hline \multicolumn{2}{|c|}{ Flowering } & \multicolumn{2}{c|}{ Maturity } \\
\hline 2014-15 & $\mathbf{2 0 1 5 - 1 6}$ & $\mathbf{2 0 1 4 - 1 5}$ & $\mathbf{2 0 1 5 - 1 6}$ \\
\hline 122 & 125 & 173 & 180 \\
\hline 120 & 123 & 161 & 169 \\
\hline 120 & 123 & 164 & 171 \\
\hline 120 & 123 & 164 & 172 \\
\hline 119 & 122 & 158 & 166 \\
\hline 117 & 120 & 154 & 161 \\
\hline 119 & 122 & 165 & 173 \\
\hline 120 & 123 & 169 & 177 \\
\hline 120 & 123 & 166 & 174 \\
\hline 119 & 122 & 160 & 168 \\
\hline 120 & 123 & 168 & 176 \\
\hline 121 & 124 & 173 & 179 \\
\hline 0.88 & 2.59 & 0.50 & 1.34 \\
\hline
\end{tabular}

*NPK- Through fertilizers, FYM- Farmyard manure, WCS- Wheat cut straw, GM- Green manure

Table.5 Grain and straw yield (kg/ha) of wheat as affected by different treatments during 2014 and 2015

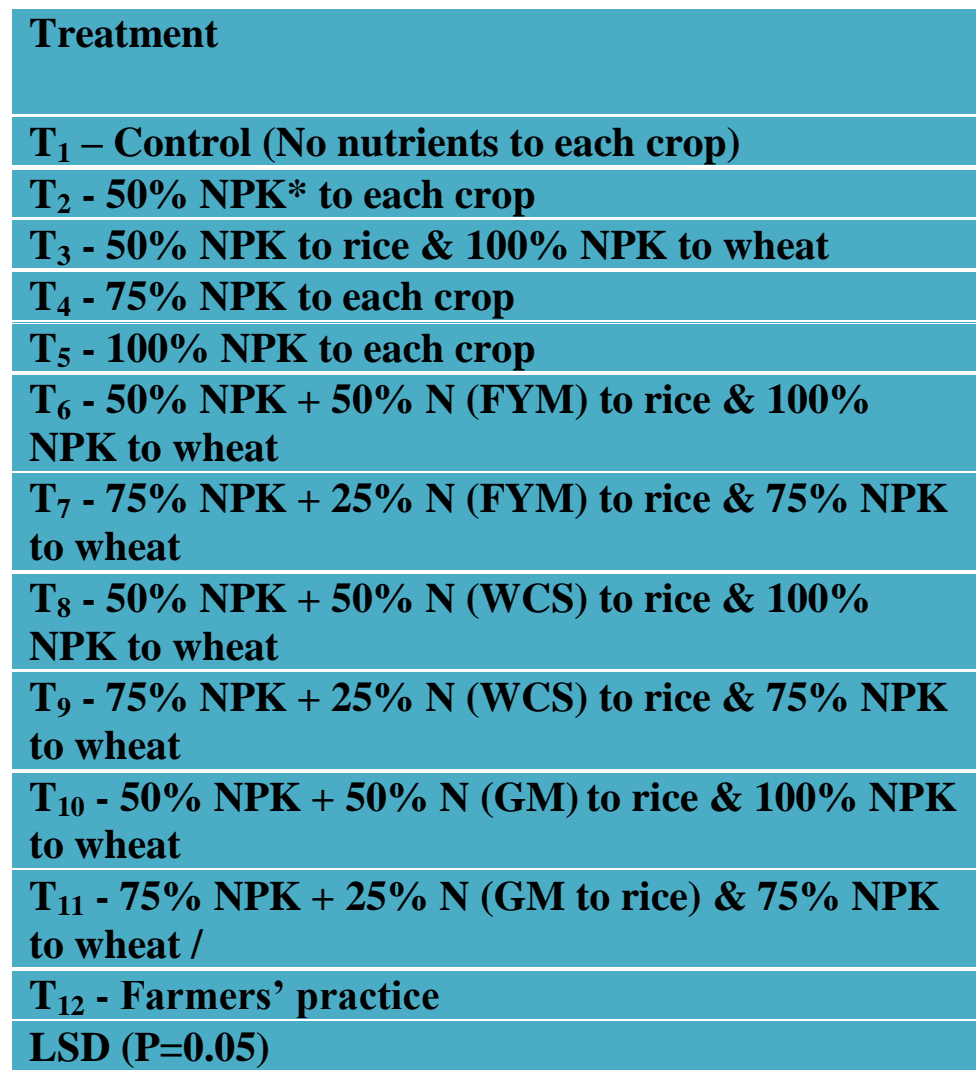

\begin{tabular}{|c|c|c|c|}
\hline \multicolumn{2}{|c|}{ Grain yield } & \multicolumn{2}{c|}{ Straw yield } \\
\hline $\mathbf{2 0 1 4 - 1 5}$ & $\mathbf{2 0 1 5}-16$ & $\mathbf{2 0 1 4 - 1 5}$ & $\mathbf{2 0 1 5}-16$ \\
\hline 1101 & 1092 & 1947 & 3215 \\
\hline 1062 & 1392 & 3757 & 3660 \\
\hline 1490 & 2830 & 3526 & 5054 \\
\hline 1888 & 1978 & 4898 & 5193 \\
\hline 2528 & 3105 & 4160 & 5521 \\
\hline 2252 & 3485 & 4927 & 6295 \\
\hline 1701 & 3018 & 5183 & 5275 \\
\hline 1741 & 2691 & 5144 & 5048 \\
\hline 2242 & 2422 & 4347 & 4843 \\
\hline 1593 & 3039 & 4013 & 5541 \\
\hline 1446 & 2466 & 4849 & 5363 \\
\hline 1397 & 2124 & 3914 & 3877 \\
\hline NS & 470 & 1160 & 968 \\
\hline
\end{tabular}

*NPK- Through fertilizers, FYM- Farmyard manure, WCS- Wheat cut straw, GM- Green manure 
Fig.1 Mean monthly weather data at Palampur (HP) for the period November 2014 and 2015 to May 2015 and 2016; rainfall, maximum temperature and minimum temperature

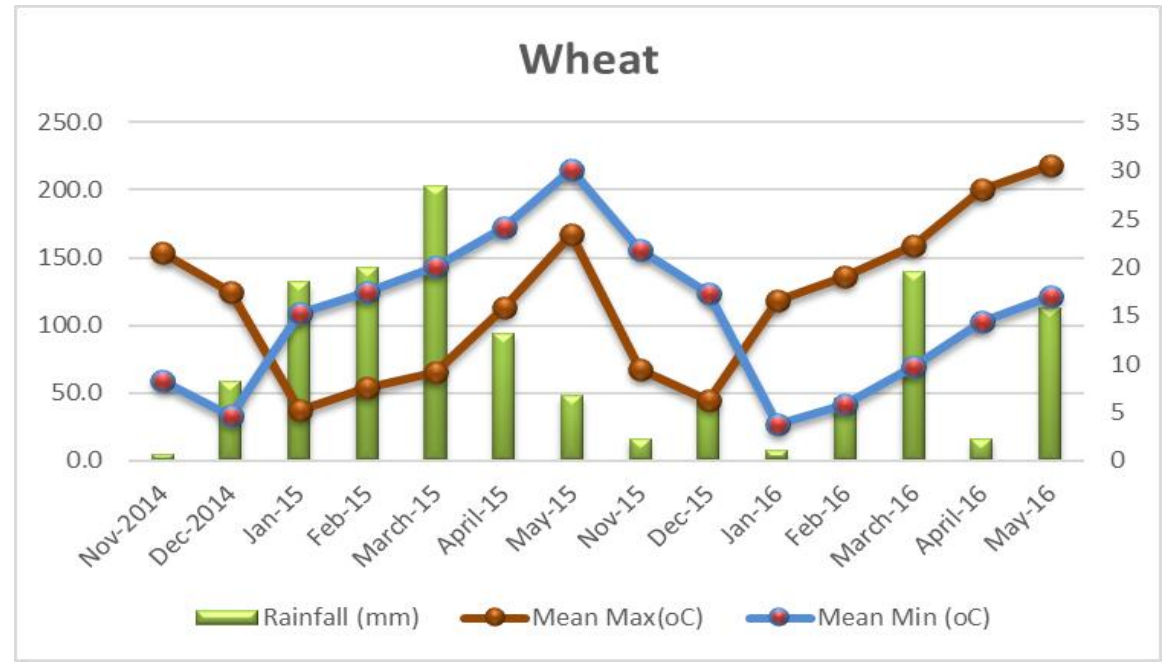

In the control wheat crop took significantly more number of days to attain $75 \%$ flowering over all other treatments during both the years.

Flowering and maturity in wheat (Table 4) were earlier in the plots manured with conjoint application of organics [FYM, green manure (dhaincha) and wheat cut straw] and fertilizers due to the direct and residual effects. Similar results were reported by Mehta (2004). This is because conjoint application of organics and chemical fertilizers resulted in early boost of vegetative growth due to better nutrition and thus, the attainment of physiological stages was enhanced. These findings are in agreement with Shah et al., (2004).

\section{Yield}

The results pertaining to the effect of integrated nutrient supply on grain and straw yield of wheat (2014-15 and 2015-16) have been presented in Table 5. A perusal of the data revealed that different treatments had significant effect on grain yield of wheat during 2015-16 and straw yield during both the years. The higher yield was owed to improved growth and development and yield attributes. Wheat grain yield during second year (2015-16) ranged from $1092 \mathrm{~kg} / \mathrm{ha}$ in control $\left(\mathrm{T}_{1}\right)$ to $3485 \mathrm{~kg} / \mathrm{ha}$ in $\mathrm{T}_{6}$ where $50 \%$ NPK through chemical fertilizer and $50 \% \mathrm{~N}$ through FYM to rice and $100 \%$ NPK to wheat through wheat cut straw during kharif. Farmers' practice too showed a significant increase $(48.6 \%)$ over the control in wheat grain yield.

Chemical fertilizers alone or in conjunction with organic materials significantly increased straw yield of wheat. The straw yield varied from a minimum of 2410 and $3295 \mathrm{~kg} / \mathrm{ha}$ in $\mathrm{T}_{1}$ (Control) to a maximum of 7194 and 7688 $\mathrm{kg} / \mathrm{ha}$ in $\mathrm{T}_{6}(50 \%$ NPK through fertilizer with $50 \% \mathrm{~N}$ through FYM to rice and 100\% NPK through fertilizer to wheat). On comparing the treatments consisting of organic materials, it was observed that $\mathrm{T}_{7}$ (75\% NPK through fertilizer with $25 \% \mathrm{~N}$ through FYM to rice and $75 \%$ NPK through fertilizer to wheat), $\mathrm{T}_{10} \quad(50 \%$ NPK through fertilizer in combination with $50 \% \mathrm{~N}$ through GM to rice and $100 \%$ NPK through fertilizer to wheat) and $\mathrm{T}_{11}(75 \%$ NPK through fertilizer with $25 \% \mathrm{~N}$ through GM to rice and $75 \% \mathrm{NPK}$ through fertilizer to wheat) were at par with 
$\mathrm{T}_{6}(50 \%$ NPK through fertilizer with $50 \% \mathrm{~N}$ through FYM to rice and $100 \%$ NPK through fertilizer to wheat), the increase was higher under FYM followed by GM and lowest in case of WCS. An increase of $10.0 \%$ and $18.7 \%$ in wheat straw yield was also recorded under farmers' practice $\left(\mathrm{T}_{12}\right)$, over control during 2014-15 and 2015-16, respectively. The omission of chemical fertilizers and organic manures for last 23-24 years (control) resulted in low yield due to continuous mining of nutrients. The integrated use of chemical fertilizers with organic manures viz., farmyard manure (FYM), wheat cut straw (WCS) and green manure (GM) obviously added nutrients to meet out the nutrients demands of the crops. Sarwar (2005) who reported that yield and different yield parameters of rice increased significantly with the use of chemical fertilizers alone or in combination with various organic materials applied in the form of Sesbania green manure,

FYM and compost in field and pot experiments (Kaur and Verma 2016). FYM is a product of microbial activity and contains large number of microbial population. Application of FYM can increase the microbial activity in the soil both by activating the microbial action and by aiding the multiplication of microbial population.

Due to these properties, application of FYM is in perfect tune with biological requirement of soil and helps to build the soil on sustainable basis. The capacity of soil to release, store and supply the plant nutrients is based on this microbial activity of soil. Large number of reports is available in the literature to show the enhanced microbial activity by application of FYM. Increased organic carbon by application of FYM has been reported to help in increased population of bacteria, actinomycetes and fungi (Upadhyay and Vishwakarma, 2014; Mitran et al., 2015; Gaind and Singh, 2015).
Wheat grain yield and straw yield during second year (2015-16) shows significant improvement in comparison to previous year. This could be attributed to more nutrient mobilization. $\mathrm{T}_{6}$ treatment where $50 \% \mathrm{NPK}$ through chemical fertilizer and $50 \% \mathrm{~N}$ through FYM to rice and $100 \%$ NPK to wheat through wheat cut straw during kharif was provided, was found better among all treatments.

In conclusion, this study highlights the impact of INM on growth, development and yield of wheat in rice-wheat cropping system. Treatment 6 (T6) performs better than other treatments which underlines the significance of INM in growth and development of crop. Flowering was earliest in T6 $50 \%$ NPK and $50 \% \mathrm{~N}(\mathrm{FYM})$ to rice and $100 \% \mathrm{NPK}$ to wheat. The maturity of wheat was also significantly affected by fertilizer treatments. Grain yield, straw yield of wheat was highest under the treatment (T6) where 50\% NPK and $50 \% \mathrm{~N}$ through FYM to rice and $100 \% \mathrm{NPK}$ through fertilizer to wheat was applied.

\section{References}

Anonymous. 2016. Area and production of Rice and Wheat. Directorate of Economics and Statistics (Department of Agriculture and Cooperation, Ministry of Agriculture. Government of India) http://eands.dacnet.nic.in/PDF/ Agricultural_Statistics_2016.pdf.

Arnon. 1972. Crop Production in Dry Region: Systematic treatment of the Principal Crops. Leonard Hill, London.

El-Gizawy. 2009. Effect of Planting Date and Fertilizer Application on Yield of Wheat under No till System. World Journal of Agricultural Sciences 5: 777-783.

Gaind S and Singh Y. 2015. Relative Efficiency of Fertilization Practices to Improve Productivity and Phosphorus Balance in Rice-Wheat Cropping System. Journal of Crop Improvement 29: 23-39. 
Ibrahim M, Anwar-ul-Hassan, Muhammad I and Ehsan EV. 2008. Response of wheat growth and yield to various levels of compost and organic manure. Pakistan Journal of Botany 40: 2135-2141.

Kalhapure A, Singh VP, Kumar R and Pandey DS. 2015. Tillage and nutrient management in wheat with different plant geometries under rice- wheat cropping system: A Review. Basic Research Journal of Agricultural Science and Review 4: 296-303.

Kaur C and Verma G. 2016. Effect of different organic sources and their combinations on weed growth and yield of wheat (Triticum aestivum). Indian Journal of Agricultural Research 50: 491-494.

Khoshgoftarmanesh AH and Kalbasi M. 2002. Effect of municipal waste leachate on soil properties and growth and yield of rice. Communication Soil Science and Plant Analysis 33: 2011-2020.

Kowsar J and Boswal MV. 2015. Effect of biofertilizer and organic fertilizer on physiological characteristics of bread wheat (Triticum aestivum). International Journal of Scientific Research and Management 3: 2073-2089.

Lathwal, O.P., S.P. Goyal and R.S. Chauhan. 2010. Introduction of summer mungbean in rice-wheat cropping system in Haryana. Indian Journal of Fertilizers 6: 37-39.

Mehta S. 2004. Effect of integrated nutrient supply on growth and yield of wheat (Triticum aestivum). Annals of Agricultural Research 25: 289-291.

Meulen AD and Chauhan BS. 2017. A review of weed management in wheat using crop competition. Crop Protection 95: 38-44

Mitran T, Mani PK, Basak N, Majumder D, Roy M. 2015. Long-term manuring and fertilization influences soil inorganic phosphorus transformation vis-a-vis rice yield under rice-wheat cropping system.
Archives of Agronomy and Soil Science 61: 1-18.

Parewa HP and Yadav J. 2014. Response of fertility levels, FYM and bio inoculants on yield attributes, yield and quality of wheat. Agriculture for Sustainable Development 2: 5-10.

Puli, M.R., P.R.K. Prasad, P.B. Ravindra, M. Jayalakshmi and S.R. Burla. 2016. Effect of organic and inorganic sources of nutrients on rice crop. Oryza 53: 151-159.

Ray SS and Gupta RP. 2001. Effect of green manuring and tillage practices on physical properties of puddled loam soil under ricewheat cropping system. Journal of Indian Society Soil Science 49: 670-678.

Reddy S. 2004. Agronomy of Field Crops. Kalyani Publishers, New Delhi, India.

Shah K, Shafi M, Anwar S, Bakht J, Khan AD. 2004. Effect of nitrogen and phosphorus application on the yield and yield components of wheat. Sarhad Journal of Agriculture 20: 347-353.

Sharma, R. 2009. Effect of long-term integrated nutrient management system on soil and crop productivity in rice-wheat crop sequence Ph.D. thesis, Department of Agronomy, CSK Himachal Pradesh Krishi Vishvavidyalaya, Palampur, India.

Upadhyay VB and Vishwakarma SK. 2014. Longterm effect of integrated nutrient management in rice (Oryza sativa)-wheat (Triticum aestivum) cropping system. Indian Journal of Agronomy 59: 209-214.

Yadav, D.S. and A. Kumar. 2009. Long-term effect of nutrient management on soil health and productivity of rice (Oryza sativa)-wheat (Triticum aestivum) system. Indian Journal of Agronomy 54: 15-23.

Yadav, R. L. and K. Prasad. 1998. In: Annual Report 1997-98. PDSR, Modipuram, U.P., India, P 36-49.

\section{How to cite this article:}

Gunjan Guleria, S.S. Rana, Rachana Rana and Amit Kumar Singh. 2018. Influence of Integrated Plant Nutrition System on Growth, Development and Yield of Wheat in Rice-Wheat Cropping System in Hilly Area of India. Int.J.Curr.Microbiol.App.Sci. 7(09): 795-803.

doi: https://doi.org/10.20546/ijcmas.2018.709.095 